\title{
THE EFFECT OF INNER FAN BLADE ANGLE TO THE VENTILATION RATE OF THE TURBINE VENTILATOR
}

\author{
Priyo Agus Setiawan ${ }^{1}$, Triyogi Yuwono ${ }^{2}$ \\ ${ }_{1}^{1}$ Politeknik Perkapalan Negeri Surabaya, Jl. Teknik Kimia Kampus ITS, Surabaya, Indonesia \\ 2Institut Teknologi Sepuluh Nopember, Kampus ITS, Keputih-Sukolilo, Surabaya, Indonesia \\ Telp: (031) 5947186, Fax: (031) 5942887 \\ E-mail: priyo.as@ppns.ac.id
}

\begin{abstract}
Geographical location of Indonesia country has relative wind speed lower than the countries of turbine user e.g. Finland, United States of America, and other countries. Turbine ventilator can be used as ventilation within wind energy driver. The turbine ventilator generates drag force and causes rotated turbine ventilator. This rotation generates a negative pressure inside turbine ventilator and inhaled air. The previous study revealed that the performance of turbine ventilator signifies at low wind speed. Indonesia has low wind speed, thus it should be relevant to assemble the additional inner fan in turbine ventilator. The research method was applied by conducting the experiment to test the effectiveness of turbine ventilator placed above plenum $1 \mathrm{~m} \times 1 \mathrm{~m} \times 2.3 \mathrm{~m}$. NACA 0015 was used for blade inner fan with a variety of inner fan blade angles $15^{\circ}, 30^{\circ}, 45^{\circ}$ and $60^{\circ}$ and varied wind speed to turbine ventilator $1.5,3,4.5$ and 6 $\mathrm{m} / \mathrm{s}$. The turbine ventilator used in this research was about 18 inches in size to measure flow rate over the plenum. Inner fan rotated at $500 \mathrm{rpm}$. The results of the experiment reveal that rotating turbine ventilator increased the flow rate at an inner fan blade angle of 45 degrees and maximum ventilation rate was at inner fan blade of 45 degree angle.
\end{abstract}

Keywords: turbine ventilator, blade angle, flow rate, NACA 0015

\section{INTRODUCTION}

The most important part of the building to supporting life by the changing of air in the building in order to feasibly used human was ventilation. In Central Europe and Northern, ventilation used to producing clean air for breathing and it was also used to removing the contaminant. Fresh air supply was good for health about $7 \mathrm{l} / \mathrm{s}$ per person by [1].

Turbine ventilator was a wind turbine with a vertical axis has a combined function of wind turbine and a suction fan. Turbine ventilators uses wind energy instead of ventilation fans of electrically powered. This equipment was often used on the roof have the function as ventilation in residential and industrial buildings. Wind energy blowing on the turbine ventilator blades would produce drag force and caused the turbine ventilator to rotate. This rotation produced negative pressure inside the turbine ventilator so that air was inhaled from the bottom of the channel. The air entered the turbine axially through the bottom of the channel and exit was radial.
A pattern of airflow around the turbine ventilator had been carried out by [2]. The air flow was divided into two streams when the air through the ventilator. One stream was in the direction of rotation and becomes a rotary force, while the other is in the opposite direction and dampens the rotation of the ventilator. The rotating blades throw the expelled air particles and combined the both of air flow above, which converge was in the wake region on the opposite side of the blowing wind. In the same study, three ventilators size were measured at diameter 6 , 14 and 20 inches with wind speed between 10 and $30 \mathrm{~m} / \mathrm{s}$. Lai found that the larger the ventilator diameter would cause the ventilation rate increasing as expected.

Lai [3] had tested wind turbine by comparing turbine ventilator performance by adding of inner fan combined with solar cells as small-scale power plants. The inner fan blade was drawn air from inside the channel by taking lift produced on the inner fan blade. A similar study by [4] compared the performance of the turbine ventilator by adding photovoltaic 
as a small-scale energy generator to move the inner fan. However, using photovoltaic had a worse performance than turbine ventilators without the addition of photovoltaic at certain wind speeds.

Khana et al., [5] presented a study about the flow rate measurement of four commercial turbine ventilators on a specially designed experimental system. The ventilation flow rate and turbine ventilator speed was calculated at different wind speeds and then compared by a simple open column and two standard turbine ventilators. This study also explained using of DC motors as ventilator drive when there is no wind and power consumption to the given flow rate and compared the flow rate between all types of turbines driven by the wind to turbine driven DC motor.

Most of the turbine ventilators use an inner fan with an axial flow fan type by Bleier at al., [6]. Thus, the axial flow fan approach is carried out to know the performance of the inner fan. In the axial flow fan, air flows in the axial direction and the flow is parallel to the rotating axis of the inner fan. This flow is not disturbed before it reaches the inner fan blade. Then, the blade fan deflects flow and the basic principle of axial flow fan is the deflection of wind flow caused by airfoil and fan type.

The turbine ventilator has conducted by Aaron et al. [7], Fatah et al. [8] and Rasamimanana et al. [9]. Aaron et al. [7] studied the effect of exhaust hood angle to the performance of turbine ventilator by varying $36^{\circ}, 72^{\circ}$ and $108^{\circ}$ of degree with hood height constant. The results show that the increasing hood angle increasing the performance of turbine ventilator with improving flow rate. Fatah et al. [8] studied the effect of the ratio of length duct and turbine ventilator diameter by 1,2 dan 3 . The results show that the low ratio generated the power more than high ratio. Rasamimanana et al. [9] studied the effect of nozzle type variations to the performance turbine ventilator by varying $18^{\circ}, 9^{\circ}$ and $6^{\circ}$ with the channel diameter dan hood diameter kept constant. The results show that the increase of the nozzle angle increasing the power.

Design for human comfort can be done by planning ventilation components such as ducts, turbine ventilator and etc. The design of ducting had been conducted by Setiawan et al. [10] studied numerical simulation of reattachment formation with respect to changing of tee duct obstacle hight. Domain simulation use duct size $15 \mathrm{~cm} \times 15 \mathrm{~cm}$ with a length of inlet and outlet 1 meter each and height of obstacle varied (t/D) of 0.5 and 1 . The results show that height of obstacle duct $t / D$ of 1 can reduce reattachment length.

Widiarti et al. [11] studied the evaluation of natural ventilation with numerical simulation of computational fluid dynamics (CFD) as an effect of k3 control in the welding workshop of Shipbuilding Institute of Polytechnic Surabaya. The results show that air velocity is permitted is $0.25-0.5 \mathrm{~m} / \mathrm{s}$. Results of contour have a velocity less than $2.25 \mathrm{~m} / \mathrm{s}$. The welding workshop control is very good by installing a cyclone turbine ventilator that helps move air.

These studies had provided information and knowledge. The development of the research was still carried out until now. This research would be tested on an existing turbine ventilator in the market and modification to know the effect on ventilation rate. The modifications that would be applied to the turbine ventilator was provided adding inner fan with the rotation kept constant coupled to a DC motor instead of a photovoltaic. Lai [3] did not couple directly between inner fan and turbine ventilator because it would cause energy losses on the turbine ventilator. Therefore, Lai [3] provides energy photovoltaic to rotating the inner fan. This present study, Inner fan was placed on the channel and variation of the inner fan blade angle. Obtained performance data would be compared by means of an inner fan and without modification. This test was applied to several variations of free air flow (free stream) with reference to the average wind speed in territory Indonesian from 1 to $10 \mathrm{~m} / \mathrm{s}$.

\section{METHOD AND MATERIAL}

The present study uses experimental to get data information. In this experiment, the turbine ventilator was placed above of the plenum chamber, which an axial fan would blow fresh air into the turbine ventilator to simulating the wind speed as shown in Fig.1. Turbine ventilator was mounted on a plenum with sizing (length $x$ width $x$ height) $1 \mathrm{~m} \times 1 \mathrm{~m}$ $x 2.3 \mathrm{~m}$.

When the axial fan was turned on at certain wind speeds, the turbine ventilator 
rotates to produce a negative pressure in the each point is taken as much as 10 times data plenum and then the inner fan was turned on retrieval and the value would be averaged to to help produce a negative pressure. The reducing the measurement error.

amount of negative pressure was measured by using pressure transducer in two parts of the system, namely: the channel after the inner fan and plenum box. Wind speed was measured by using an anemometer mounted between the turbine ventilator and the axial fan. Data retrieval was carried out at some point, where

The rotary encoder was mounted on the axis of the turbine ventilator to measuring the rotational speed of the turbine ventilator. Pressure measurement was also used to determining the velocity of existing wind flow in the channel after passing the inner fan. Wind speed was used to finding the flow rate.

Table. 1 Specification of set up experimental

\begin{tabular}{c|l|l}
\hline No & \multicolumn{1}{|c}{ Equipment } & \multicolumn{1}{c}{ Specification } \\
\hline 1 & Turbine ventilator & Aluminium Curved ID:0.457; OD:0.607; Ltotat :0.924 \\
\hline 2 & Blower & Axial Flow CKEC901-41430 rpm 300 It/min \\
\hline 3 & Blade of Inner fan & Airfoil NACA 0015 Chord 5 cm, Number of blades : 4 (Variable) \\
\hline 4 & $\begin{array}{l}\text { Pressure } \\
\text { Transducer }\end{array}$ & $\begin{array}{l}\text { Sensor and Signal Conditioning: PTPX655-05BDI, Pitot Static } \\
\text { Tube } \\
\text { Signal Processing: AVR Micro System; Connector: USB TO } \\
\text { RS232 HE 800A; Computer: Lenovo Intel Atom S10-3 }\end{array}$ \\
\hline 5 & $\begin{array}{l}\text { Measurement of } \\
\text { RPM }\end{array}$ & $\begin{array}{l}\text { Sensor: Optocoupler, Encoding Wheel; Signal Conditioning: } \\
\text { IC74HC132, Signal Processing: AVR Micro System; Display: EMS } \\
\text { LCD Display }\end{array}$ \\
\hline 6 & Control of RPM & $\begin{array}{l}\text { Sensor: Potensio meter multitude; Signal Processing: AVR Micro } \\
\text { System; Actuator: EMS30AH-Bridge; Motor: Sutrak 24VDC 3000 } \\
\text { rpm; Resistant Measurement: AVO meter }\end{array}$ \\
\hline 7 & Anemometer & Omega Digital Anemometer CFM Master II \\
\hline 8 & Inverter & Altivar 312 3kW 3HP-380-500 93 \\
\hline 9 & Power & 1 Adaptor 24VDC 5A and 2 Adaptor 5V DC 500 mA \\
\hline 10 & Plenum Chamber & Wood and Acrylic, size 2.3 m x 1m x 1m \\
\hline
\end{tabular}
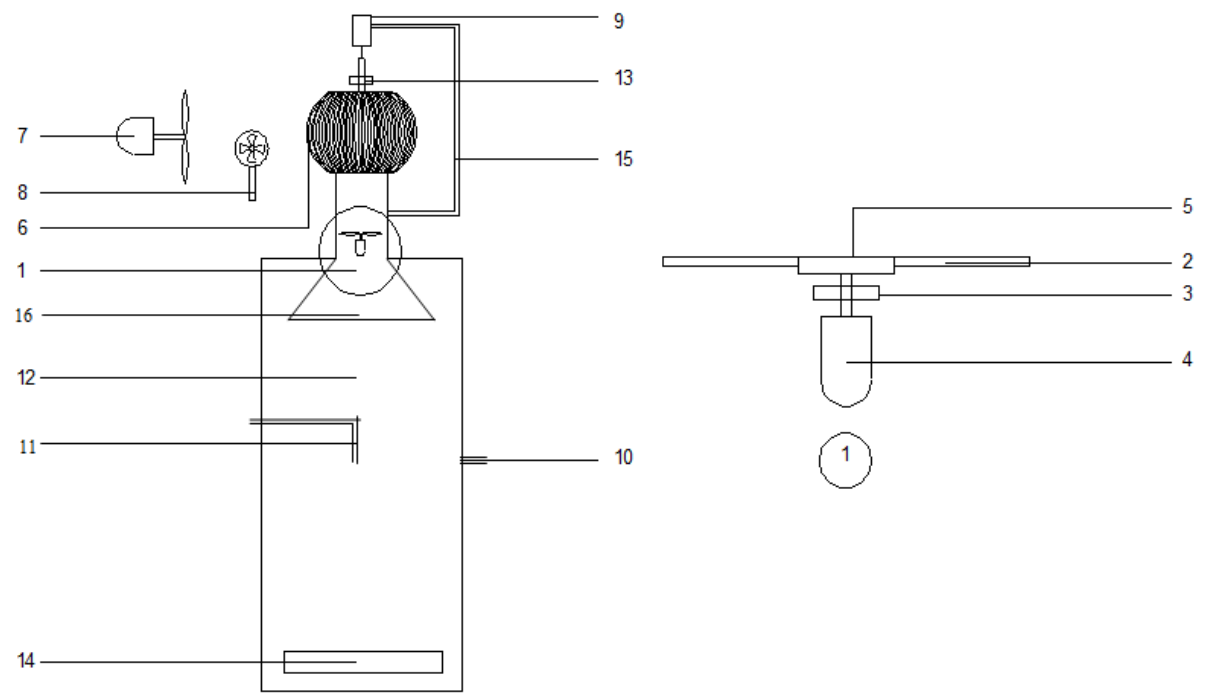

Fig. 1 Set up experimental 


\section{Description of Fig. 1}
1. Inner fan
2. Inner fan Blade
3. Rotary Encoder of inner fan
4. Inner fan Motor
5. Hub
6. Turbine ventilator
7. Blower
8. Anemometer

The angle change of the inner fan blade was used to determining the effect on the turbine ventilator performance. This modification was carried out on several variations of freestream speed. The effect of this modification was measured by the measurement of pressure difference in the plenum Box and the neck of the turbine ventilator. The position of this gauge could be seen in Fig. 1 and specification of set up experimental shown in Table. 1.

\section{Turbine Ventilator}

The experiment use turbine ventilator with curved formed blade sold in the market. This turbine ventilator is type of the exhaust. Details can be seen in Fig 2.

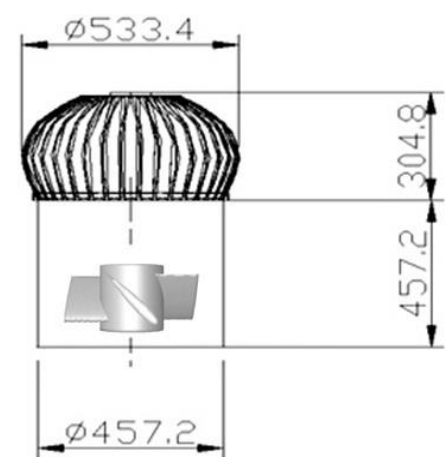

Fig 2. The dimension of Turbine Ventilator

\section{Inner Fan}

The main study uses inner fan by using NACA 0015 varied blade angle of $15,30,45$ and 60 degree. The inner fan has the function to help turbine ventilator generate a negative pressure in the room so that it can be sucked out of the room. The inner fan can be seen in fig 3.
9. DC Generator
10. Pressure Tap
11. Pitot tube
12. Plenum chamber
13. Rotary Encoder of turbine ventilator
14. Inlet fresh air
15. Support of DC Generator
16. Hood

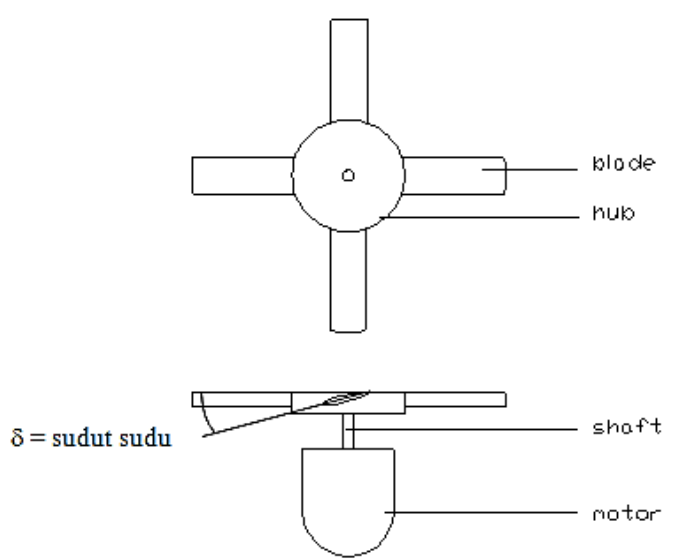

Fig 3. Inner fan

In this study, pressure measurements on the turbine ventilator chimney were carried out. Pressure tap is placed on the plenum wall (before the inner fan) and at the outlet (after the inner fan). The pressure measurement block diagram can be seen in Fig 4 . In this measurement, the pressure input is first censored with a pressure tap. Pressure is passed to the pressure of the transducer to be converted into an electrical signal. This electrical signal is read by AVO meter.

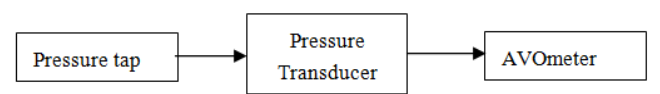

Fig 4. Block diagram of the pressure measurement

\section{Calibration Process}

In order for the pressure measurement to be valid, calibration is performed on the pressure measurement circuit. The following calibration steps.

1. Prepare calibration equipment, namely plenum, chimney, turbine ventilator, pitot static tube, pressure transducer, pressure 
measurement circuit and inclined manometer.

2. Install a static pitot tube in the center of the plenum.

3. Connect the static pressure hose and dynamic pressure to the other pitot-static tube connected to the pressure transducer.

4. Read the manometer scale at the starting position.

5. Turn on the inner fan and adjust the RPM amount in mode 10 using the RPM control circuit to get the speed in the test section as expected.

6. Reading $\mathrm{h}$ on the manometer results from pitot-static tube measurements.

7. Read the transducer pressure output on the AVO meter results of pitot-static tube measurements.

8. Repeat the 6-7 process by changing the inner fan RPM in 20,30, 40 and 50 modes.

9. So that we get a graph of the relationship between the form of pressure and voltage.

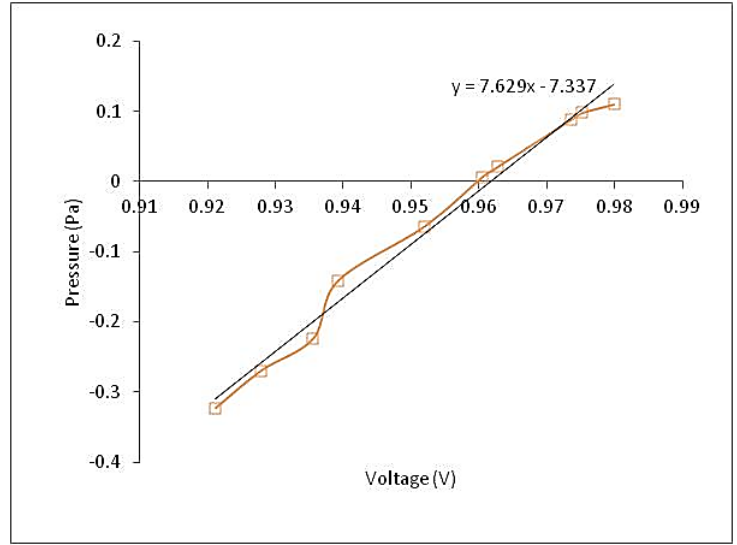

Fig 5. Calibration graph of gage Pressure

\section{Mathematical Formula}

Flow rate calculation is in the channel from turbine ventilator will be calculated by using equation follows:

$\mathrm{Q}=\overline{\mathrm{V}} \cdot \mathrm{A}$

Where $Q$ is flow rate, $V$ is the average velocity of fluid $(\mathrm{m} / \mathrm{s})$ and $A$ is the area of the plenum chamber.
Average velocity over inlet plenum using the following equation:

$$
\mathrm{Q}=\mathrm{n} \cdot \overline{\mathrm{V}}_{\text {inlet }} \cdot \mathrm{A}_{\text {inlet }}
$$

Where Ainlet is area of inlet plenum, $\mathrm{n}$ is number of inlet plenum.

Flow rate coefficient $\left(\mathrm{K}_{\mathrm{Q}}\right)$ using the following equation:

$\mathrm{K}_{\mathrm{Q}}=\frac{\mathrm{Q}}{\mathrm{U}_{\infty} \cdot \mathrm{c}^{2}}$

Where $K_{Q}$ is flow rate coefficient, $U_{\infty}$ is free stream velocity, $\mathrm{C}$ is chord of inner fan NACA 0015

\section{RESULTS AND DISCUSSION Pembahasan Grafik}

The Evolution of the rotational speed of the turbine ventilator was as a function of the wind speed for the angular change of angles as shown in Fig 6 that greater wind speed would cause the momentum of wind flow is greater so that would cause to increase drag force of turbine ventilator. With increasing the momentum of wind flow with constant inertia turbine ventilator would increase the velocity of the turbine ventilator.

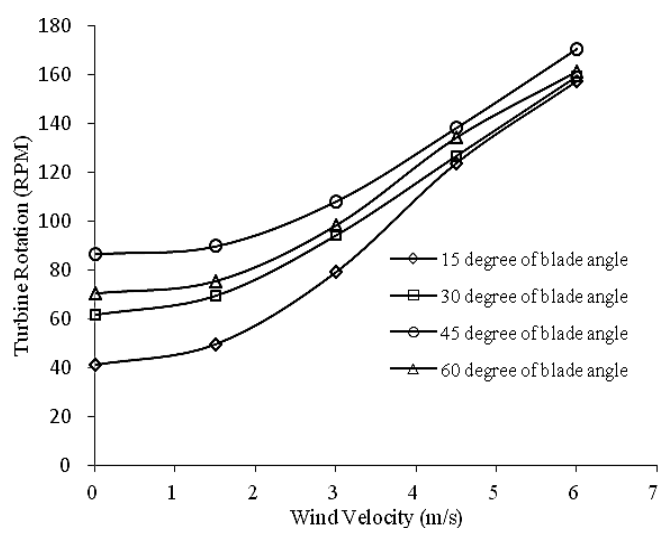

Fig. 6 Graph of turbine ventilator rotation velocity as the function of wind velocity for the changing of blade angle

The wind speed was kept constant by increasing the angle of the inner fan blade until 45 of degree however the turbine ventilator rotation increased. The phenomenon showed 
that the adding of blade angle would give the addition of fluid power. The turbine ventilator had additional energy however the rotational speed of the turbine ventilator increased showing that the increase of the inner fan blade angle would decrease the relative angle of inner fan causing the increase of the absolute velocity at constant linear inner fan velocity. The greater the absolute velocity would be accelerated from the inlet rotor to the exit as energy rate was produced the fluid by the rotor per unit of mass flow rate from the channel flow or neck. The adding of energy rate to the fluid flow by the rotor was specified as the radial velocity between the hubs to the tip. The increasing of energy rate would add the rotation speed of turbine ventilator.

When the increasing of blade angle until 60 of degree would cause blade chord tending to align towards the fluid flow direction in channel or neck however the tangential velocity would increase.

The tangential velocity component would occur at the frame reference as a result of the swirl appearance, where the greater tangential velocity component would increase the swirl so that it would increase the pressure loss or called the head loss. The increasing of head loss would tend to decrease the rotational speed of the turbine ventilator.

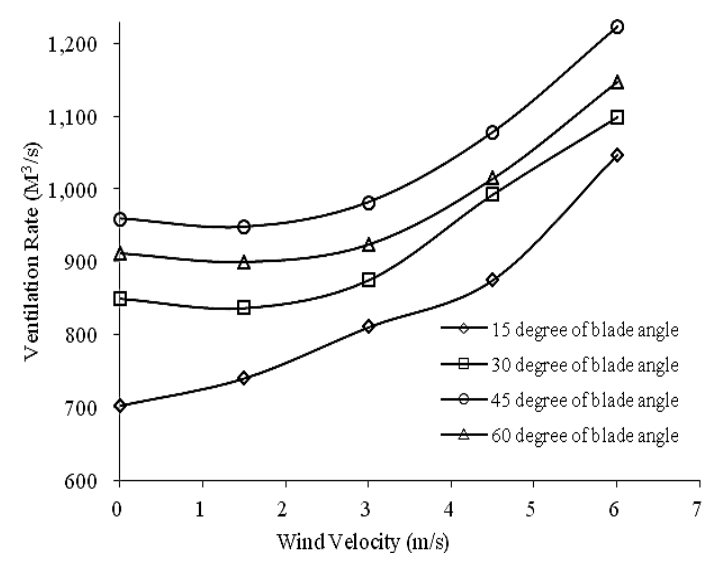

Fig. 7 Graph of the flow rate as the function of wind speed for the changing of blade angle

Graph the flow rate as the function of wind speed for the changing of the blade angle as shown in Fig. 7. The increasing of wind velocity would cause increase wind momentum followed the increasing of the moment of momentum from turbine ventilator. The increasing of the moment of momentum the turbine ventilator would cause increasing the rotation of turbine rotation so it would tend to reduce the drag towards flow over the channel causing the increase of the flow rate by increasing the rotation of turbine ventilator.

Wind velocity was kept constant by the increasing of the inner fan blade angle until 45 of degree possible to raise the torque of the turbine ventilator however the rotation of turbine ventilator increased. But the angle of the inner fan blade was larger than 45 of degree, position angle of the inner blade decreased the rotation of turbine ventilator. The decreasing of the turbine ventilator rotation indicated the weakening of the vacuum in plenum so that it would decrease the ventilation rate.

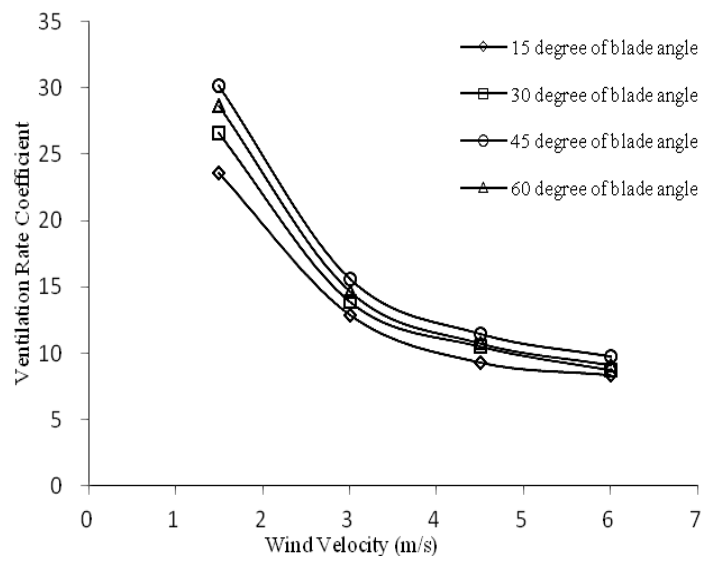

Fig. 8 Graph of the ventilation rate coefficient as the function Reynolds number for the changing of blade angle.

Graph of the ventilation rate coefficient as the function Reynolds number for the changing of blade angle as shown in Fig. 8. The ventilation rate coefficient tended decrease by increasing wind velocity. The ventilation rate coefficient equation explained that the magnitude of the ventilation rate was inversely proportional to the wind velocity, where the ventilation rate was rise not proportional to the changing in velocity so the trend of the ventilation rate coefficient decreased by the increase of the Reynolds number. 
At the constant wind velocity, the increasing of the blade angle of inner fan would increase the ventilation rate coefficient and reach the maximum of ventilation rate coefficient at 45 degree of blade angle. This indicated by increasing blade angle of the inner fan increasing the ventilation rate so it increased the ventilation rate coefficient. The ventilation rate coefficient would decrease by increasing the blade angle until 60 of degree because the ventilation rate at 60 degrees occurred decreasing as shown in Fig. 8. The graph showed trending proportional between the ventilation rate and the ventilation rate coefficient, so the ventilation rate coefficient decreased at the blade angle of the inner fan at 60 of degree.

\section{CONCLUSION}

The blade angle of inner fan influenced the turbine rotation, the ventilation rate and coefficient of the ventilation rate of turbine ventilator. The results of the experiment show that the maximum the ventilation rate occurred at 45 degrees of blade angle.

\section{DAFTAR PUSTAKA}

[1] Awbi, Hazim, B., (1998),"Renewable and Sustainable Energy Reviews 2", Pergamon, chapter 7, hal. 157-188.

[2] Lai, C., M., "Experiments on the ventilation efficiency of turbine ventilators used for building and factory ventilation", Journal of Energy and Buildings, Vol. 35, Elsevier, hal. 927-932, 2003.

[3] Lai, C., M., "Prototype development of rooftop turbine ventilator powered by hybrid wind and photovoltaic energy", Journal of Energy and Buildings, Vol. 38, Elsevier, hal. 174-180, 2006.

[4] Shun, Simon and Noor A. Ahmed (2008), Utilizing wind and solar energy as power sources for a hybrid ventilation device, Journal of Renewable Energy, Vol. 33, Elsevier, hal. 1392-1397.
[5] Khana, Naghman, Yuehong, S., U., Saffa, B., Riffat and Colin Biggs (2008), "Performance testing and comparison of turbine ventilators", Journal of Renewable Energy, Vol. 33, Elsevier, hal. 2441-2447.

[6] Bleier and Frank, P., (1997), "Fan, handbook: Selection, aplication and design", McGraw-Hill.

[7] Aaron, S., K., Yuwono T., dan Widodo, W., A., (2011), "Investigasi eksperimental dan numerik terhadap aliran udara dalam ventilator turbine exhaust hood dan verifikasi kerjanya dalam menghasilkan energi", Master's thesis, Teknik Mesin ITS, Surabaya.

[8] Fatah, M., Yuwono T., dan Widodo, W., A., (2011), "Studi experimental dan numerik pengaruh rasio panjang dan diameter turbine ventilator terhadap unjuk kerja turbine ventilator", Master's thesis, Teknik Mesin ITS, Surabaya.

[9] Rasamimanana, A., F., Yuwono T., dan Widodo, W., A., (2011), "Studi eksperimental dan numerik aliran udara melalui turbine ventilator dengan exhaust hood type nozzle", Master's thesis, Teknik Mesin ITS, Surabaya.

[10] Setiawan, P., A. dan Subekti, A.,"Simulasi Numerik Terbentuknya Reattachment Length Terhadap Perubahan Tinggi Obstacle Pada Tee Duct', Inovtek Polbeng 7 (2), 188-193, 2017.

[11]Widiarti, Y., Rosydah, B., M., dan Setiawan, P., A.,"Evaluasi Ventilasi Alami Dengan Simulasi Numerik Computational Fluid Dynamics Sebagai Upaya Pengendalian K3 Pada Bengkel Las Politeknik Perkapalan Negeri Surabaya", Jurnal Teknik Mesin 21 (2), 2014. 